\title{
Stress of conscience as a risk factor for burnout among ICU nurses in University Medical Centre Maribor
}

\author{
Saša Šajn Lekše, Bernarda Lončar, Alenka Žibert, Andrej Starc \\ University of Ljubljana, Faculty of Health Sciences, Zdravstvena pot 5, 1000 Ljubljana, Slovenia \\ sasa.sajn.lekse@gmail.com; bernarda.loncar5@gmail.com; ibert.alenka@gmail.com; \\ andrej.starc@zf.uni-lj.si
}

\begin{abstract}
Introduction: A nurse's conscience is an important factor in clinical decision-making. Conscience can be clean or troubled; it can warn, encourage or judge. A troubled conscience appears when a person neglects the voice of their own conscience. When related to the quality of the provided service, a troubled conscience can cause stress. Work related stress is defined by endogenous and exogenous factors: the presence of various environmental stressors and the individual's coping ability. A prolonged period of exposure to stressful situations may lead to occupational burnout. Burnout is a state of physical and emotional exhaustion originating in an individual's internal processes, but triggered by external burden. Individuals with burnout syndrome exhibit symptoms of depression, anxiety and depersonalisation. Method: A descriptive method was used. A literature search was performed between March and June 2017 in databases CINAHL with full text and MEDLINE. Results: Stress of Conscience Questionnaire appears to be a valid instrument for measuring the stress of conscience in various situations in healthcare. The questionnaire has already been translated into Slovene language and will be applied in a future research within the intensive care units of UKC Maribor. Discussion: A troubled conscience can cause burnout symptoms, especially in intensive care units where patients are monitored constantly by highly trained professional teams. Key words: workplace stress, occupational burnout, intensive care nursing, mental health, nurse.
\end{abstract}

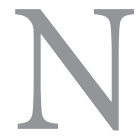

urses perform effective professional decision making every day. Not only professional expertise affects their decisions, but also their attitudes, values, personality and constraints of healthcare organisation. And yet, sometimes there are adverse consequences. If the outcome is unfortu- 
nate, severe psychological stress, combined with feelings of guilt and troubled conscience can occur.

\section{Conscience and troubled conscience}

Conscience is an integral part of professional decision-making. At the beginning of life, conscience in general is formed through parental values. Religious values and various extrinsic factors are also important. Conscience in relation to established social norms can influence "judgement" which can cause an internal conflict (Thompson et al., 2006; Weinstock, 2014). People describe their conscience as "the voice that tells them what to do." It guides towards "good" and discourages "evil". Some religious theories interpret the voice of conscience as the voice of God. The Old Testament argues that a person has two choices. Conscience is God's emissary or teacher, but man himself must decide between his two tendencies towards good or evil (Fromm, 1987; Wood, 2009).

Trstenjak (1971) describes conscience as a compass that directs nurses towards professional goals by protecting against reckless decisions. There are two extremes: dulled conscience, navigating in the wrong direction and extra-sensitive conscience, acting as a brake. Properly formed conscience will not cause discomfort. Nurses with properly formed conscience constantly receive internal support for their professional conduct. Conscience helps to administer ethical standards to concrete situations. It accompanies every professional decision. A troubled conscience is sadness in conjunction with the idea of a past unexpected event and is a sign of helplessness. Nurses mention a troubled conscience when they are not able to provide sufficient high-quality care and when nurses do something, but at the same time know that this should not be done. Troubled conscience is followed by feelings of guilt (De Spinoza, 1988; Kelly, 1998; Strandberg and Jansson, 2003; Genuis and Lipp, 2013).

\section{Stress and occupational burnout}

Stress is defined as a physiological, psychological and behavioural response to stressors. A stressor can be an event, a person or an object (Dernovšek et al., 2006) which triggers a physiological response. Stress has many negative connotations, although positive stress is also possible. Stress becomes negative when individuals cannot control the situation or find themselves in distress that is impossible to deal with. Long-term negative stress results in deterioration of health, emotions and behaviour, signalling work overload. (Yehuda 2002; Hafner and Ihan, 2014).

In the past, burnout was initially only associated with caring professions (Selič, 2010). Occupational burnout is the result of prolonged workplace stress. The first questionnaire for burnout assessment was developed in 1981, measuring three dimensions: emotional exhaustion, depersonalization and personal fulfilment (Maslach and Jackson, 1981; Hafner and Ihan, 2014). Burnout occurs when discrepancies between the nature of work and the nature of man appear. 
Indicators of discrepancies are: overload, lack of supervision, inadequate financial benefits, absence of strong workplace community, lack of honesty and conflicts of values. All discrepancies contribute to burnout, and focusing on the individual exclusively will not have the desired effect. Some individuals will seek refuge in their work as a solution to their personal problems. Burnout develops slowly over the years, making it difficult to diagnose and treat. Burnt out individuals are chronically tired, experience headaches, sleep disturbances, vomiting, changes in nutrition, are alienated from their work and feel that they are becoming less effective, motivated and more cynical. Complete burnout is a state of physical, emotional and mental fatigue and classified as a problem related to life management. Burnout is a gradually expanding disintegration of values, spirit and mood. Depression and anxiety are also common. One of the results of prolonged stress could be a stroke experience, heart attack and suicide (Maslach and Leiter, 1997; SZO, 2006; Hafner and Ihan, 2014).

Nursing care in intensive care units (ICU)

One of the nursing roles is supporting the treatment plan. Nurses in the ICU are known for their systematic and integrated approaches, which require psychophysical abilities and personality traits allowing a responsible attitude towards the patient (Kodila, 2008; Makovec, 2009). Healthcare workers need to be highly qualified, requiring theoretical knowledge, responsibility, and experience for an immediate professional response, making the ICU itself a constant stressor (Mealer et al., 2007; Polovšak, 2009). The psychological effects of stress are relatively unknown, but are related to the environment where treatment is complex and mortality of patients is high. Consequently, nurses may become irritable, depressed and frustrated. Continuous stress and the inability to adapt can cause burnout symptoms (Badger, 2001; Jonsson et al., 2003; Mealer et al., 2007).

Burnout in healthcare systems is often overlooked, because the focus is on caring, and professionals often do not recognise their own vulnerabilities. The authors are preparing a study on the impact of troubled conscience on burnout in a sample of ICU nurses in University Clinical Centre Maribor. The chosen research instrument was the Swedish Stress of Conscience Questionnaire (Glassberg et al., 2006). The aim of the article is to present results of studies that previously used the questionnaire to confirm its usability in Slovenian context.

\section{Methods}

A descriptive method was used. A literature search was performed in March 2017 in databases CINAHL with Full Text and MEDLINE. We used the exact search phrase "stress of conscience questionnaire". All studies that included registered nurses were chosen for the review, excluding the validation studies of the questionnaire. The final analysis included 6 studies, as seen in figure 1. 


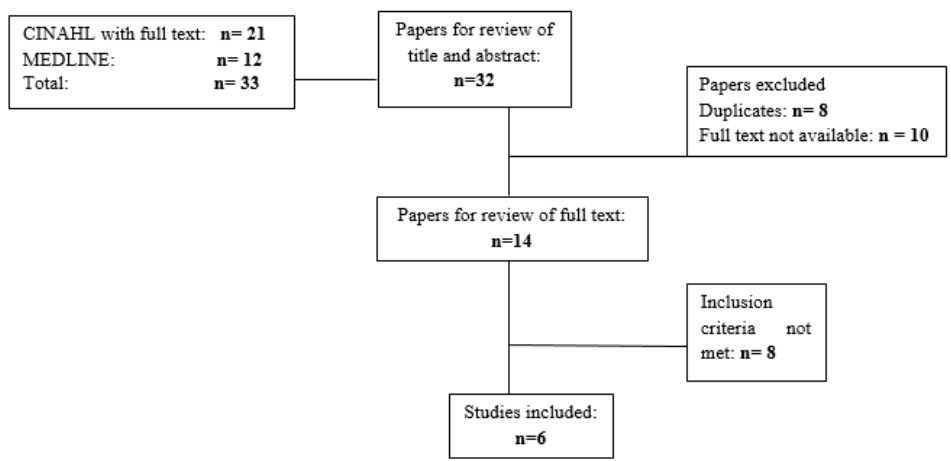

Figure 1: Literature search process.

\section{Results}

The following table (table 1) describes the main study characteristics of studies where Stress of Conscience Questionnaire (SCQ) was used to measure the stress of conscience in healthcare professionals

Table 1: SCQ study characteristics.

\section{AUTHORS}

Most often there is not enough time for quality patient care.

Analysis of the importance of the factors that contribute to the occurrence of burnout of health professionals. 2007

Exploring the factors that

Glasberg et al., 2008 contribute to stress of conscience or to the stress caused by a troubled conscience in health care.
Survey study 423 respondents
Same as above

Most troubled conscience is caused by the fact that work is so demanding that it leaves too little time for family. Emotional exhaustion and depersonalisation can be largely explained by the stress of conscience.

Stress of conscience can mainly be explained by the perception of conscience and moral sensitivity. Health workers that cannot follow the voice of their own conscience at work experience more stress of conscience.

Female respondents had significantly higher averages compared to males in items about external demands and restrictions in health care. 


\begin{tabular}{|c|c|c|c|}
\hline AUTHORS & $A I M$ & METHOD & RESULTS \\
\hline $\begin{array}{l}\text { Juthberg et al., } \\
2007\end{array}$ & $\begin{array}{l}\text { Exploring the connection } \\
\text { between the stress of con- } \\
\text { science, perceptions of con- } \\
\text { science and burnout in car- } \\
\text { egivers of the elderly. }\end{array}$ & $\begin{array}{l}\text { Multiple questionnaires } \\
146 \text { respondents }\end{array}$ & $\begin{array}{l}\text { Not enough time for qual- } \\
\text { ity patient care and work } \\
\text { is too demanding to leave } \\
\text { enough time for family. } \\
\text { Private life rarely interferes } \\
\text { with work. }\end{array}$ \\
\hline $\begin{array}{l}\text { Juthberg et al., } \\
2010\end{array}$ & $\begin{array}{l}\text { Exploring the relation- } \\
\text { ship between perceptions } \\
\text { of conscience, stress of con- } \\
\text { science and burnout in re- } \\
\text { lation to occupational be- } \\
\text { longing. }\end{array}$ & $\begin{array}{l}\text { Same as above } \\
\text { Additional statistical anal- } \\
\text { ysis }\end{array}$ & $\begin{array}{l}\text { Not enough time for qual- } \\
\text { ity patient care and work } \\
\text { is too demanding to leave } \\
\text { enough time for family. } \\
\text { Private life rarely interferes } \\
\text { with work. }\end{array}$ \\
\hline $\begin{array}{l}\text { Saarnio et al., } \\
2012\end{array}$ & $\begin{array}{l}\text { Testing the Finnish version } \\
\text { of SCQ to explore the stress } \\
\text { of conscience on staff who } \\
\text { care for elderly with de- } \\
\text { mentia. }\end{array}$ & $\begin{array}{l}\text { Survey study } \\
\text { Stratified sampling } \\
436 \text { respondents from } 45 \\
\text { different institutions. }\end{array}$ & $\begin{array}{l}\text { Not enough time for qual- } \\
\text { ity patient care and work } \\
\text { is too demanding to leave } \\
\text { enough time for family. } \\
\text { Health professionals rare- } \\
\text { ly avoid patients or relatives } \\
\text { who need help. }\end{array}$ \\
\hline $\begin{array}{l}\text { Tuvesson et al., } \\
2012\end{array}$ & $\begin{array}{l}\text { Exploring the connection } \\
\text { between environmental } \\
\text { and individual factors and } \\
\text { the stress of conscience in } \\
\text { psychiatric nursing. }\end{array}$ & $\begin{array}{l}\text { Multiple questionnaires } \\
93 \text { respondents }\end{array}$ & $\begin{array}{l}\text { The variability of SCQ re- } \\
\text { sults is largely influenced } \\
\text { by a sense of moral burden. } \\
\text { Higher moral sensitivity } \\
\text { has a greater impact during } \\
\text { ethical dilemmas, leading } \\
\text { to a troubled conscience. }\end{array}$ \\
\hline
\end{tabular}

\section{Discussion}

Nursing is associated with various stressors. In Slovenia, stress and burnout has been studied among mental health nurses (Čuk and Klemen, 2010; Peterka Novak et al., 2010; Bregar et al., 2011; Nemec and Čuček Trifkovič, 2017), emergency nurses (Kugonič, 2013) and community nurses (Kaučič, 2002). Conscience, troubled conscience and burnout in Slovenian nurses was described by Pahor and Peternelj in 2003, but the results have not been published. The existing literature also does not offer any research on conscience in ICU nurses, so the authors decided to contribute to the field with their own study. Judging by the results of the literature review, the SCQ is suitable for our research. However, due to lack of experience in scientific research, the authors were not fully prepared for the amount of time needed before the actual start of the study.

It seems that stress of conscience is strongest when lack time for quality patient care is present and when the complexity and shift of the job does not allow enough time for family. Troubled conscience appears in situations where patients are mistreated. On the other hand, avoiding patients or their family members is not a cause of troubled conscience, because healthcare professionals rarely avoid patients or relatives who need their help. Stress of conscience is an important risk factor for burnout in nurses (Glasberg et al., 2007; Juthberg et al., 2010; Saarnio et al., 2012). Theoretically, we should conclude that nurses often suppress their conscience to allow the working process to contin- 
ue. This problem should be addressed by leadership of every healthcare institution to ensure the quality of service and preserve nurses' mental health at the same time.

\section{Conclusions}

Everyday professional demands can become a burden and lead to burnout. Nursing practice is associated with many situations that might cause a troubled conscience. Stress of conscience can contribute to burnout. Further research in the area would help identify early symptoms of burnout. The authors have drafted a protocol of a quantitative research study, which will be conducted among nurses working in two ICUs in the University medical centre Maribor, currently in the process of obtaining the appropriate permissions. The study is currently in the process of obtaining all necessary permissions before beginning actual data collection. The authors will use a Slovenian version of the SCQ. With our findings we wish to encourage changes which might help to reduce occupational burnout caused by a troubled conscience, and thus to improve the mental health of nurses in the ICU.

\section{References}

BADGER, J.M., 2001. Understanding secondary traumatic stress. The american journal of nursing, vol. 101, no. 7, pp. 26-32.

BREGAR, B., PETERKA NOVAK, J. and MOŽGAN B., 2011. Doživljanje stresa pri zaposlenih $\mathrm{v}$ zdravstveni negi na področju psihiatrije. Obzornik zdravstvene nege, vol. 45, no. 4, pp. 253-62.

ČUK, V. and KLEMEN, J., 2010. Izgorevanje osebja v zdravstveni negi na psihiatričnem področju. Obzornik zdravstvene nege, vol. 44, no. 3, pp. $179-87$.

DE SPINOZA, B., 1988. Etika. Ljubljana: Slovenska matica, pp. 246.

DERNOVŠEK, M.Z., GORENC, M. and JERIČEK, H., 2006. Ko strese stres. Kako prepoznati in zdraviti stresne, anksiozne in depresivne motnje. Ljubljanja: Inštitut za varovanje zdravja Republike Slovenije, pp. 8.

FROMM, E., 1987. Človekovo srce: njegov demon dobrega in zla. Ljubljana: Državna založba Slovenije, pp. 12.

GENUIS, S.J. and LIPP, C., 2013. Ethical diversity and the role of conscience in clinical medicine. Internationa journal of family medicine, vol. 2013, pp. 587541 .

GLASBERG, A.L., ERIKSSON, S. and NORBERG, A., 2007. Burnout and 'stress of conscience' among healthcare personnel. Journal of adcanced nursing, vol. 57, no.4, pp. 392-403.

GLASBERG, A.L., ERIKSSON, S. and NORBERG, A., 2008. Factors associated with 'stress of conscience'in healthcare. Scandinavian journal of caring sciences, vol. 22, no. 2, pp. 249-258. 
GLASBERG, A.L., ERIKSSON, S., DAHLQVIST, V., LINDAHL, E., STRANDBERG, G., SÖDERBERG, A., SØRLIE, V. and NORBERG, A., 2006. Development and initial validation of the stress of conscience questionnaire. Nursing ethics, vol. 13, no. 6, pp. 633-648.

HAFNER, M. and IHAN, A., 2014. Prebujanje: Psiha v iskanju izgubljenega Erosa- psihonevroimunologija. Ljubljanja: Alpha center: Inštitut za preventivno medicino, pp. 83-470.

HARPER, D., 2001. "Conscience," Online Etymology Dictionary. [viewed 6 May 2017]. Available from http://www.etymonline.com/index.php?ter$\mathrm{m}=$ conscience\&allowed_in_frame $=0$.

JONSSON, A., SEGESTEN, K. and MATTSSON, B., 2003. Post-traumatic stress among Swedish ambulance personnel. Emergency medicine journal, vol. 20, no. 1, pp. 79-84.

JUTHBERG, C., ERIKSSON, S., NORBERG, A. and SUNDIN, K., 2007. Perceptions of conscience in relation to stress of conscience. Nursing ethics, vol. 14, no. 3, pp. 329-343.

JUTHBERG, C., ERIKSSON, S., NORBERG, A. and SUNDIN, K., 2010. Perceptions of conscience, stress of conscience and burnout among nursing staff in residential elder care. Journal of advanced nursing, vol. 66, no. 8, pp. $1708-1718$.

KAUČIČ, B.M., 2002. Proces izgorevanja pri članih negovalnega tima v patronažnem varstvu. Obzornik zdravstvene nege, vol. 36, no. 2, pp. 101104.

KELLY, B., 1998. Preserving moral integrity: a follow-up study with new graduate nurses. Journal of advanced nursing, vol.28, no. 5, pp. 1134-1145.

KODILA, V., 2008. Osnovni vodnik po kirurški enoti intenzivnega zdravljenja. Priročnik za medicinske sestre in zdravstvene tehnike. Ljubljana: Univerzitetni klinični center Ljubljana, pp. 21-35.

KUGONIČ, N., 2013. Sindrom izgorevanja pri zaposlenih v nujni medicinski pomoči. Obzornik zdravstvene nege, vol. 47, no. 3, pp. 268-75.

MAKOVEC, V., 2009. Dokumentiranje in standardi, protokoli zdravstvene nege $\mathrm{v}$ Enoti intenzivne terapije. In: 18. simpozij intenzivne medicine in 15. seminar intenzivne medicine za medicinske sestre in tehnike zdravstvene nege. Zbornik predavanj. Bled: Slovensko združenje za intenzivno medicino, pp. 174-180.

MASLACH, C. and JACKSON, S.E., 1981. The measurement of experienced burnout. Journal of occupational behavior, no. 2, pp. 99-113.

MASLACH, C. and LEITER, M.P., 1997. Resnica o izgorevanju na delovnem mestu. Ljubljana: Educy, pp. 9-19.

MEALER, M.L., 2007. Increased prevalence of post- traumatic stress disorder symptoms in critical care nurses. American journal of respiratory and critical care medicine, vol. 175, no. 7, pp. 693-697. 
NEMEC, U. and ČUČEK TRIFKOVIČ, K., 2017. Stres med zaposlenimi na področju psihiatrične zdravstvene nege. Obzornik zdravstvene nege, vol. 51, no. 1, pp. 9-23.

PAHOR, M. and PETERNELJ, K., 2003. Vest, slaba vest in izgorelost pri medicinskih sestrah; preliminarna predstavitev mednarodne raziskave. In: KLEMENC, D., KVAS, A., PAHOR, M. and ŠMITEK, J., eds. Zdravstvena nega v luči etike: Društvo medicinskih sester in zdravstvenih tehnikov Ljubljana, pp. 368-369.

PETERKA NOVAK, J., BREGAR, B., MOŽGAN, B. and VAJDA, A., 2010. Dejavniki, ki povzročajo stres pri zaposlenih v psihiatrični zdravstveni negi. In: BREGAR, B. and PETERKA NOVAK, J., eds. Kako zmanjšati stres in izgorelost na delovnem mestu: zbornik predavanj z recenzijo / Seminar sekcije medicinskih sester in zdravstvenih tehnikov v psihiatriji, Ljubljana, 12. november 2010. Ljubljana: Zbornica zdravstvene in babiške nege - Zveza strokovnih društev medicinskih sester, babic in zdravstvenih tehnikov Slovenije, pp. 24-29.

POLOVŠAK, S., 2009. Fizične in psihične posledice stresa na delovnem mestu. In: Raznolikost odzivanja na stresne situacije - 4. modul medsebojni odnosi kot temelj kakovosti v zdravstvu. Logarska dolina: Spes, društvo za kulturo odnosov, pp. 33-36.

SAARNIO, R., SARVIMÄKI, A., LAUKKALA, H. and ISOLA, A., 2012. Stress of conscience among staff caring for older persons in Finland. Nursing ethics, vol. 19, no. 1, pp. 104-115.

SELIČ, P., 2010. Stres in izgorelost: kako je mogoče razumeti in uporabiti podatke o izgorelosti na primarni ravni ravni zdravstvenega varstva. In: BREGAR, B., PETERKA NOVAK, J., eds. Kako zmanjšati stres in izgorelost na delovnem mestu: zbornik predavanj z recenzijo / Seminar sekcije medicinskih sester in zdravstvenih tehnikov v psihiatriji, Ljubljana, 12. november 2010. Ljubljana: Zbornica zdravstvene in babiške nege - Zveza strokovnih društev medicinskih sester, babic in zdravstvenih tehnikov Slovenije, pp. 7-18.

STRANDBERG, G. and JANSSON, L., 2003. Meaning of dependency on care as narrated by nurses. Scandinavian journal of caring sciences, vol. 17, no. 1, pp. 84-91.

SVETOVNA ZDRAVSTVENA ORGANIZACIJA, 2006. Mednarodna klasifikacija bolezni in sorodnih zdravstvenih problemov za statistične namene. 2nd ed. Ljubljana: Inštitut za varovanje zdravja Republike Slovenije, pp. 1010.

THOMPSON, R.A., MEYER, S. and MCGINLEY, M., 2006. Understanding values in relationships: The development of conscience. Handbook of moral development, pp. 267-297.

TRSTENJAK, A., 1971. Človek samemu sebi. Ljubljana: Mohorjeva družba, pp. 50-53. 
TUVESSON, H., EKLUND, M. and WANN-HANSSON, C., 2012. Stress of Conscience among psychiatric nursing staff in relation to environmental and individual factors. Nursing ethics, vol. 19, no. 2, pp. 208-219.

WEINSTOCK, D., 2014. Conscientious refusal and health professionals: does religion make a difference? Bioethics, vol. 28, no. 1, pp. 8-15.

WOOD, A.W., 2009. »Kant on conscience«. In: Kantovsky Sbornik. Jubilee edition dedicated to Leonard Aleksandrovich Kalinnikov. [viewed 6 May 2017]. Available from: https://web.stanford.edu/ allenw/webpapers/KantOnConscience.pdf

YEHUDA, R., 2002. Post-traumatic stress disorder. The new england journal of medicine, vol. 346, no. 2, pp.108-114. 